\title{
Comprehensive Evaluation of E-commerce Performance in Small and Medium-Sized Tourism Enterprises: A Resource-Based Analysis
}

\author{
Hui Song ${ }^{1,2}$ \\ ${ }^{1}$ School of Management Engineering, Suzhou University, \\ Suzhou city, Anhui province, 234000, China \\ ${ }^{2}$ Research Center of Northern Anhui Urban-rural Integration \\ songhuisuzhou@163.com
}

\begin{abstract}
Since the 1990s, along with the progress of information technology, the development of electronic commerce is growing rapidly. With the aid of tourism e-commerce information platform, it can provide modern tourist services and tourist products in the short term. In this paper, we made empirical analysis of how the electronic commerce and network platform will effect on tourism consumption. The results shows that enterprise network level and travel website will both have positive influence to online travel ticket sales, LnNE at lag 1 period increased one percentage will lead LnOTS increased by 0.018, and LnWE at lag 1 period increased one percentage will lead LnOTS increased by 0.209. So that, e-commerce application has positive effect on tourism consumption. On this basis, we put forward relevant suggestions.
\end{abstract}

Keywords: E-commerce; Rural tourism; Customer satisfaction; Internet economy

\section{Introduction}

Since the 1990s of last century, along with the progress of information technology and development of the world economy has entered a new economy represented by the internet economy era; the development of electronic commerce is growing by leaps and bounds. Because the tourism industry itself has run across the characteristics of regional and industrial added value high, can well meet people's growing spiritual and cultural consumption demand, especially under the push of ecommerce, its business scope and development field is expanded constantly [1]. It is in this background, tourism electronic commerce has a rapid development in the western developed countries, and shows strong vitality, become the government department of tourism management, tourism industry and the majority of travel enthusiasts to be bestowed favor on newly [2]. In fact, the tourism electronic commerce is an important part of modern economy is to promote world economic development and industrial structure adjustment and optimization of the effective means and important tool.

Modern tourism industry belongs to a typical application of sensitive information, technology intensive and high value-added services, its inherent characteristics makes it very suitable for the development of electronic commerce business, namely the tourism electronic commerce. Especially the ongoing industrial upgrading and economic structure change of our country, actively contribute to the combination of tourism and modern information technology, vigorously develop tourism electronic commerce in our country, not only can improve the overall level of development of tourism in our country, more can improve the quality of service level, management of China's tourism and economic benefits [3]. Therefore, China should seize the rare 
historical opportunity for development, through the Internet and e-commerce to enhance the core competitiveness of tourism industry in our country, makes every effort to obtain greater competition in the global economic competition advantage. Vigorously develop the tourism e-commerce is conducive to China's tourism resources of our country the development of low cost and fast speed of integration. As is known to all, the traditional pattern of tourism development because of the lack of modern information technology equipment, its development speed, strength, and benefit in the short term it is hard to have big, especially in the Midwest and remote mountain areas to the rich tourism resources into modern tourism product and the direct economic benefit is more difficult. At the same time, one of the advantages of e-commerce is its low cost, high benefit management characteristics. With the aid of tourism e-commerce information platform, can in the short term will quickly into the rich tourism resources in our country modern tourist services and tourist products.

\section{Literature Review}

In the late $1980 \mathrm{~s}$, American management scientist Piers [4] first use the concept of "tourism flow", it is usually considered a modern tourism electronic commerce as originally envisioned and bud. Werthner and Ricci (2004) based on the Angle of modern tourism industry supply chain, system analysis and the internal flow of information between the tour industry organizations [5]. Then made a serious study of tourism market characteristics, thus put forward the tourism electronic commerce through the information platform can effectively achieve seamless docking between tourism supply and demand, and established the regression analysis model of tourism electronic commerce information release, acquisition, sorting, and application and so on a series of information process and efficiency of research. Constanta (1998) use data from Netherlands, Japan and France, applying the idea of project development and operation in the field of engineering technology to make empirical analysis [6]. From the perspective of industry chain, Constanta expounds the importance of tourism development network, was proposed based on ONTOUR (The Open Network for tourism) network of tourism development projects. Attaches great importance to the study of the tourism electronic commerce information infrastructure construction, it is through complete and efficient information facilities and equipment, tour industry organizations to be able to provide customers with personalized travel products and services.

Because tourism is a highly integrated information service industry, therefore in the process of the development of the tourism electronic commerce must attach great importance to the generation and transfer of information. Friedman (2006) proposed the tourism electronic commerce mode based on recommendation systems [7]. In this model, tourism consumers can easily query to tourism destinations and related supporting tourism services. At present, the western countries about the research and development of the tourism electronic commerce information database is under rapid development, the more popular version is mainly as Buhalis (1998); Williams (1999) and Buhalis \& Law (2008) [8-10].Study of tourism e-commerce in China started late, but due to the fast economic and social development in China in recent years, the research presents the vigorous development trend. Xiong (2006) starting from the basic meaning and the main characteristics of e-commerce, combining with the characteristics of China's tourism development and exploratory development in our country tourism electronic commerce, he presents the basic supply of market demand, and the preliminary development countermeasures [11]. Lin (2004) pointed out that in view of the tourism electronic commerce needs more system information database, so our country tourism electronic commerce operation 
mode to telecoms companies or large e-commerce sites as the main body [12] Cheung (2006) through to the western tourism electronic commerce development research, and find out the key to the success or failure of the tourism electronic commerce is to timely solve the problem of consumer's online payment [13]. Then put forward our country should attach great importance to tourism based on the informatization construction of e-commerce and online payment information encryption. Zheng (2009) pointed out that strengthen the importance of one-to-one marketing, especially for different gender, age, occupation or purposefully developed different interests of tourists tourism electronic commerce service marketing based on segments[14]. Qin (2004) according to the customer relationship management in the modern service marketing theory, and points out that to develop the tourism electronic commerce in china [15].They pointed out that enterprise must pay attention to the customer relationship management of tourism consumers, implementation of "take the customer as the center" marketing and management strategy, take various measures to build a complete, safety information management system, in maintaining the existing tourism consumers, on the basis of expanding new potential tourism consumers.

\section{Data and Methodology}

\subsection{The Current Situation of Tourism in Anhui Province}

Tourism in Anhui province gradually implemented by a single product to multiple products, small to large, self-development to joint development, extensive management to intensive management, averaging to further expand the international and domestic tourism market, tourism product development, production and sale of gradually formed system, tourism infrastructure improved significantly. The number of inbound tourism in Anhui province in 2013 is 3.855 million, than going up year of growth $16.3 \%$; 336 million domestic tourists, growth of $15 \%$. The total tourism income 301.04 billion yuan, grow $15.3 \%$. Among them, the tourist foreign exchange income of USD 1.73 billion, an increase of $15.8 \%$; domestic tourism income 290.32 billion yuan, grow $15.3 \%$. At the end of the year, the province has more tourist attractions (area) 461. Anhui tourism electronic commerce development, not only the requirement of Anhui tourism development degree is high, but also has a good ecommerce environment. In this paper, based on the investigation to the macro environment of electronic commerce in Anhui, found that the network client base development more quickly, the new professional website is increasing. In recent years in Anhui province, $\mathrm{CN}$ domain name grew by 51660, the total growth rate of $65.2 \%$, but is still relatively slow growth relative to the $\mathrm{CN}$ domain name, accounts for the proportion reduced year by year. We summarized the internet users and growth rate data during 2005-2013 in Anhui province, as shown in Figure 1. According to the related research found that the Internet and regional economic development level is associated with the degree of development, that is the more advanced the regional economy, the Internet was developed, in Anhui province's overall economic level is relatively backward, GDP per person is relatively low compared with the other area. 


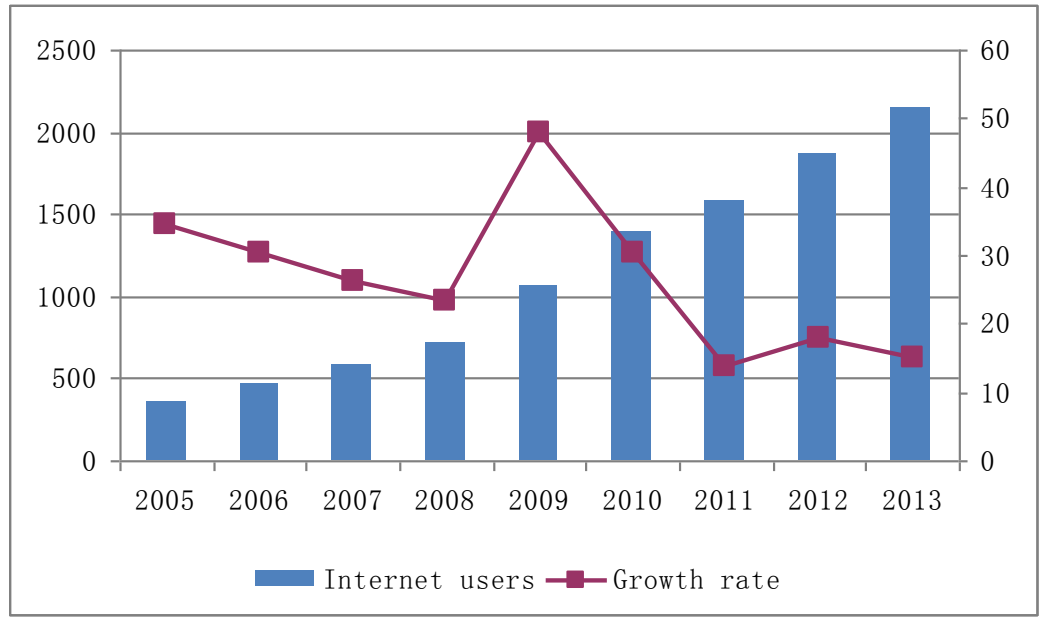

Figure 1. Internet Users and Growth Rate

\subsection{Nonlinear VAR Mode}

Vector auto regression (VAR) is a statistical model used to capture the linear interdependencies among multiple time series. An estimated VAR model can be used for forecasting, and the quality of the forecasts can be judged. We assume the VAR (Q) model as following:

$$
\left[\begin{array}{l}
y_{1} \\
x_{2}
\end{array}\right]=\left[\begin{array}{l}
\beta_{1} \\
\gamma_{1}
\end{array}\right]+\left[\begin{array}{ll}
\alpha_{1} & \alpha_{2} \\
\varphi_{1} & \varphi_{2}
\end{array}\right]\left[\begin{array}{l}
y_{t-1} \\
x_{t-1}
\end{array}\right]+\ldots+\left[\begin{array}{l}
e_{1} \\
e_{2}
\end{array}\right]
$$

In this formula, Q is the lag augmentation of VAR model. We consider now that coefficients that determine causal relationships in the VAR $(\alpha 2 q$ and $\varphi 1 q)$ are not stable but change over time following a logistic smooth transition functional form as:

$$
\begin{aligned}
& \alpha_{2 q}=a_{2 q}^{*}+a_{2 q}^{* *} F\left(\lambda_{1 q}, c_{1 q} ; \tau\right) \\
& \alpha_{1 q}=\varphi_{1 q}^{*}+\varphi_{1 q}^{* *} F\left(\theta_{1 q}, g_{1 q} ; \tau\right)
\end{aligned}
$$

As the transition variable is time, $\mathrm{clq}$ and $\mathrm{g} 1 \mathrm{q}$ are interpreted as the timing of the transition midpoint. The midpoint break date would simply be equal to (c1q $\mathrm{T}+\mathrm{T} / 2$ ) or $(\mathrm{g} 1 \mathrm{q} T+\mathrm{T} / 2)$. These timing coefficients can be determined endogenously through a grid search procedure, as will be discussed later on, so the researcher does not need to know the break point a priori.

\subsection{Variable Description}

In this paper, the variables involved are "Online travel ticket sales", "Enterprise network level", "Travel website number", "Enterprise information investment", all variables were shown in table 1 . The online travel ticket sale means online travel ticket sales, it is the dependent variable, and other variables are independent variables. Enterprise network level means corporate computer ownership and Internet access rate, notes as "NE"; Travel website number means number of building and online travel sites, notes as "WE". 
Table 1. Variable Description and Definition

\begin{tabular}{|c|c|c|}
\hline Variables & Definition & Abbreviation \\
\hline $\begin{array}{c}\text { Online travel ticket } \\
\text { sales }\end{array}$ & online gross travel bookings in Anhui province & OTS \\
\hline Enterprise network level & $\begin{array}{c}\text { Corporate computer ownership and Internet } \\
\text { access rate }\end{array}$ & NE \\
\hline Travel website number & Number of building and online travel sites & WE \\
\hline
\end{tabular}

\section{Results and Discussion}

\subsection{ADF Unit Root Test}

Data stable is the premise of establishing VAR model, an augmented DickeyFuller test (ADF) is a test for a unit root in a time series sample. We use ADF unit root test to inspect LnOTS, LnNE and LnWE, the result as is shown in table 2. Through the test results we can see that LnOTS, LnNE and LnWE are -1.671,$0.252,-1.984$, so that all data were unstable. Then we made differential processing in all data, and find out all data were stable, and then we can use granger test and cointegration test.

Table 2. Result of Augmented Dickey-Fuller Test

\begin{tabular}{|c|c|c|c|c|c|}
\hline Variables & Test Statistic & $\begin{array}{c}1 \% \\
\text { Critical Value }\end{array}$ & $\begin{array}{c}5 \% \\
\text { Critical Value }\end{array}$ & $\begin{array}{c}10 \% \\
\text { Critical Value }\end{array}$ & Result \\
\hline LnOTS & -1.671 & -3.709 & -2.983 & -2.623 & unstable \\
\hline LnNE & -0.252 & -3.709 & -2.983 & -2.623 & unstable \\
\hline LnWE & -1.984 & -3.709 & -2.983 & -2.623 & unstable \\
\hline D.LnOTS & -3.862 & -3.709 & -2.983 & -2.623 & stable \\
\hline D.LnNE & -4.053 & -3.709 & -2.983 & -2.623 & stable \\
\hline D.LnWE & -3.922 & -3.709 & -2.983 & -2.623 & stable \\
\hline
\end{tabular}

\subsection{VAR Model}

According to the analysis above, we try to use VAR regression model to test the impact of enterprise network level, travel website number to the online travel ticket sales. First, we make the empirical analysis of LnOTS and LnNE .Before constructing the VAR model, the lag of VAR Model should be determined. By using STATA software to calculate the lag length, the result shows that the optimal lag length is at lag 2.

Table 3. Selection-Order Criteria

\begin{tabular}{|c|c|c|c|c|c|c|c|c|}
\hline lag & LL & LR & df & $\mathrm{p}$ & FPE & AIC & HQIC & SBIC \\
\hline 0 & 49.816 & & & & .000022 & -5.03327 & -5.01645 & -4.93386 \\
\hline 1 & 84.561 & 69.49 & 4 & 0.00 & $1.1 \mathrm{e}-06$ & -8.08088 & -7.99676 & $-7.97134^{*}$ \\
\hline 2 & 86.768 & 11.414 & 4 & 0.35 & $8.8 \mathrm{e}-07^{*}$ & $-8.26959^{*}$ & $-8.21911^{*}$ & -7.58381 \\
\hline 3 & 90.254 & 16.971 & 4 & 0.13 & $1.2 \mathrm{e}-06$ & -8.02676 & -7.90898 & -7.33086 \\
\hline 4 & 95.994 & 21.481 & 4 & 0.02 & $1.1 \mathrm{e}-06$ & -8.20998 & -8.05855 & -7.31525 \\
\hline
\end{tabular}

By choosing lag 2, then the VAR model for LnOTS and LnNE can be shown as table 4.According to the result, it shows that the enterprise network level will promote the online travel ticket sales. LnNE at lag 1 period increased one percentage will lead LnOTS increased by 0.018 percentage, and LnNE at lag 2 period increased one percentage will lead LnOTS increased by 0.032 percentage. So 
the effect of LnWE to LnOTS is obvious. Therefore, enterprise network level is an important factor and will have positive effect to online travel ticket sales.

Table 4. The Result of VAR Model for LnOTS and LnNE

\begin{tabular}{|c|c|c|c|c|c|c|c|}
\hline \multicolumn{2}{|c|}{ LnOTS } & Coef. & Std. Err. & $\mathrm{z}$ & $\mathrm{P}>|\mathrm{z}|$ & \multicolumn{2}{c|}{ [95\% Conf. Interval] } \\
\hline LnOTS & L1. & .88016 & .26434 & 3.33 & 0.001 & .36206 & 1.3982 \\
\hline & L2. & -.23174 & .21852 & -1.06 & 0.289 & -.66005 & .19655 \\
\hline LnNE & L1. & .01894 & .10222 & 0.19 & 0.853 & -.21931 & .18142 \\
\hline & L1. & .03218 & .09691 & 0.33 & 0.740 & -.15776 & .22213 \\
\hline _cons & & .31569 & .13698 & 2.30 & 0.021 & .04721 & .58417 \\
\hline
\end{tabular}

Then, we make the empirical analysis of LnWE and LnOTS. According to the related research found that the Internet and regional economic development level is associated with the degree of development, that is the more advanced the regional economy, the Internet was developed, in Anhui province's overall economic level is relatively backward, GDP per person is relatively low compared with the other area. By using STATA software to calculate, the VAR model for LnWE and LnOTS can be shown as table 5. According to the result; it shows that LnWE at lag 1 period increased one percentage will lead LnOTS increased by 0.209 percentage, and LnWE at lag 2 period increased one percentage will lead LnOTS decreased by 0.0453 percentage. The result shows that the rising of travel website will have periodic impact to online travel ticket sales. It will have positive influence in the short time, but have negative influence in the long time.

Table 5. The Result of VAR Model for LnOTS and LnWE

\begin{tabular}{|c|c|c|c|c|c|c|c|}
\hline \multicolumn{2}{|c|}{ LnOTS } & Coef. & Std. Err. & $\mathrm{z}$ & $\mathrm{P}>|\mathrm{z}|$ & \multicolumn{2}{c|}{$[95 \%$ Conf. Interval] } \\
\hline LnOTS & L1. & 1.6409 & .31079 & 5.28 & 0.000 & 1.03181 & 2.2501 \\
\hline & L2. & -1.0173 & .28345 & -3.59 & 0.000 & -1.5729 & -.46180 \\
\hline LnWE & L1. & .20976 & .06755 & 3.11 & 0.002 & .07736 & .34217 \\
\hline & L1. & -.04535 & .03693 & -1.23 & 0.219 & -.11773 & .02703 \\
\hline _cons & & -.42855 & .36276 & -1.18 & 0.237 & -1.1395 & .28245 \\
\hline
\end{tabular}

\subsection{Granger Causality Test}

In order to analyze the relations between financial development and economic growth, we use granger causality test to analyze this VAR model, the result is shown in table 6.From Table 6, we can get that LnWE is the reason to LnOST, which means enterprise network level is the reason to the rising of online travel ticket sales. At the same time, LnNE is also the granger reason to LnOST, so that travel website number is also the reason to online travel ticket sales; this is also same to the conclusion above.

Table 6. Causal Relationship Test Through Granger Causality Analysis

\begin{tabular}{|c|c|c|c|c|c|}
\hline Equation & Excluded & chi2 & df & Prob > chi2 & Result \\
\hline LnWE & LnOTS & 2.6607 & 2 & 0.719 & accept \\
\hline LnOTS & LnWE & 5.0313 & 2 & 0.021 & reject \\
\hline LnNE & LnOTS & 12.210 & 2 & 0.386 & accept \\
\hline LnOTS & LnNE & 7.6891 & 2 & 0.004 & reject \\
\hline
\end{tabular}




\subsection{Impulse-Response Analysis and Variance Decomposition}

According to the results above, we can get that there exist a long-term equilibrium relationship between LnWE and LnOST, and enterprise network level is the reason to the online travel ticket sales, also the VAR model is stable. In order to analyze the VAR model, we use Impulse-response function, the results is shown in Figure 2(a) and Figure 2(b).From Figure 2(a), we can get that when LnWE received one unit impact, it will lead LnOST increase currently, LnOST at $\mathrm{t}=1$ period is 0.0038 and then increased to 0.00024 at $\mathrm{t}=2$ period. Then LnOST began to increase and reach 0.0321 at $\mathrm{t}=4$ period. It illustrates there is long-term effect between enterprise network level and online travel ticket sales. At the same time, From Figure 2(b), we can get that when LnNE received one unit impact in, it will lead LnOST increase currently, LnOST is 0.00 at $t=1$ period and decrease to -0.0069 at $\mathrm{t}=2$ period, then it become stable after $\mathrm{t}=4$ period as -0.0384 . According to the impulse analysis results, we can get that enterprise network level will significant influence the online travel ticket sales, so that it is important to the online travel ticket sales. The cholesky variance decomposition also shows the same result, the contribution degree of LnWE to LnOST is gradually increased. From Figure 2, we find the contribution degree of LnWE to LnOST at $\mathrm{t}=1$ period is 0.025 , and then increased gradually from step 2, finally increased to $39.92 \%$ at $\mathrm{t}=8$ period. At the same time, the contribution degree of LnNE to LnOST is 0 at $t=1$ period, then increased from step 2, the contribution degree in $\mathrm{t}=8$ period is $49.89 \%$. This means that enterprise network level and travel website number both has a important contribution degree to online travel ticket sales, and can be used to explain the rising of online travel ticket sales.
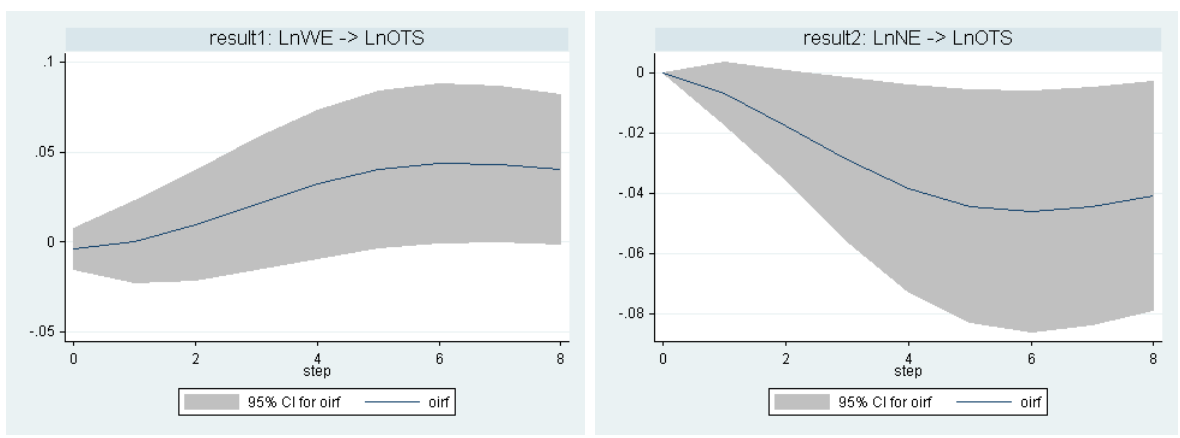

\section{Figure 2. Impulse-Response Analysis: 2(a) LnWE to LnOTS; 2(b) LnNE to LnOTS}
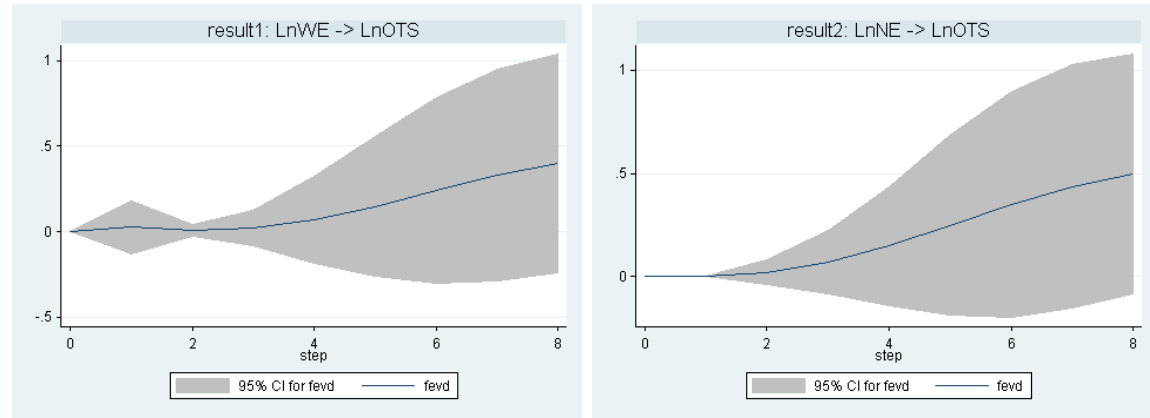

Figure 3. Contribution Degree: 3 (a) LnWE to LnOTS; 3 (b) LnNE to LnOTS 


\section{Conclusions}

\subsection{Create Good External Environment for the Development of the Tourism Electronic Commerce}

To develop the tourism electronic commerce in our country, the government responsibility. Overall speaking, the supervision department of the government in our country tourism electronic commerce development the main responsibilities is to create a good external environment, for the development of the development of the tourism electronic commerce provide strong atmosphere. Specifically, that is our country government management departments to intensify the from WE hnology, capital, taxes and the policy and law and so on various aspects of spending and help the responsibility, so as to promote sound and rapid development of the tourism electronic commerce in our country. One is strongly to informatization construction and popularization. Informatization is the important symbol of a country modernization degree; also is the foundation and guarantee to vigorously develop tourism electronic commerce. Only to establish good information infrastructure and equipment, to provide public information service for the majority of tourism service enterprises. Therefore, our country will need to increase funding, for Internet infrastructure. In addition, the government should have the courage to take on tourism e-commerce build national information service platform and the database system. Tourism electronic commerce is highly integrated information emerging service industries, higher requirements about the quality of the information management. Therefore, countries should set up our country tourism as the lead unit telecom financial for members of the public information service platform leading group, to the tourist information resources integration and planning in the country. Such as tourist traffic information, tourism, catering, tourism information, tourism information service, personalized information.

\subsection{Promote the Tourism Industry to Actively Participate in Tourism Electronic Commerce and Innovation}

In a sense, only the large number of strong comprehensive strength, the service characteristic of tourism enterprises in tourism electronic commerce can truly form our country tourism electronic commerce industry in the modern sense. At present our country tourism electronic commerce development present situation, however, is only one of the few national tourism e-commerce enterprises, such as China international travel service, China youth travel service, etc.., are mostly some other travel services, small and medium enterprises, limited to a variety of reasons, these small and medium-sized tourist service enterprises to participate in the tourism electronic commerce's enthusiasm is not high. Therefore, how to mobilize their positive development of tourism electronic business service became the key of the development of tourism e-commerce industry in China. According to the development experience of western developed countries, and combined with the concrete practice in our country, at present our country small and medium-sized tourist service enterprises can take the following several ways into tourism e-commerce: one is the rational use of the national "golden dragon project" on the implementation of public service platform; 2 it is to join a large tourism e-commerce sites; 3 it is to actively join the network tourism alliance, rectify means of development, etc.

\subsection{Strengthening the Cooperation of the Fact to Ensure Travel Safety Standards of Electronic Payment}

Due to the electronic commerce of information technology, especially the remote communication technology and Internet technology demand is higher, left the information technology can't really say tourism electronic commerce development. In the modern tourism electronic commerce, there are two main types of transmission and 
operation information, is one of the categories before trading information on business, such as information query consultation of tourism, tourist marketing and service, etc., this kind of information is the basic information of tourism consumers of tourism consumption, and you can't have left them tourism electronic commerce. Another kind is trading after payment information, it is the fundamental guarantee to realize tourism ecommerce transactions, without the participation of it cannot be called the true sense of tourism electronic commerce, but turned into a consulting and reservation online, offline settlement and payment. The key here is how to realize the tourism security, fast and convenient payment and settlement. Because when it comes to tourism e-commerce payment settlement, will involve more on economic subject, not only tourism consumers, but also have the travel service enterprise, especially financial institutions to participate. Based on this, vigorously strengthen the fact cooperation ensure the safety of the tourism electronic commerce payment settlement specification is particularly important.

\subsection{Pay Attention to Brand Marketing on Tourism Electric Business Competitive Advantage}

In the accelerating economic globalization and regional economic integration today, facing increasingly competitive environment at home and abroad and the vast majority of tourism consumers increasingly individuation, differentiation and customization of consumer demand, in the process of developing tourism electronic commerce in our country must attach great importance to brand management and marketing, highlighting your competitive advantage, and strive to build its own core competitiveness, play to the advantages of tourism electronic commerce in our country. Brand strategy for tourism ecommerce operation enterprise, itself is a kind of wealth, the other main competition in the short term it is difficult to imitate and surpass. The American management scientist Michael porter in 1976 pointed out that the market competition of the 21 st century will be based on the brand competition of enterprise culture. Based on this, the government of our country, especially the e-commerce operation enterprises should innovate actively, build the service brand, wins the general customers the trust and goodwill. Such as personalization service brand and marketing services, network brand "one-stop" service and personalized marketing is the proof of that. Due to various reasons, of course, these sites of brand strategy and marketing model also has the very strong imitativeness and machinery, but anyway we have walked on the road and chose the development strategy of the brand management.

\section{Acknowledgements}

The work of this paper is supported by National Social Science Youth Fund Project "Research on Rural Tourism Sustainable Development Strategy based on Urban-rural Integration" (No: 13CJY106)

\section{References}

[1] J. Lu and Z. Lu, "Development, distribution and evaluation of online tourism services in China," Electronic Commerce Research, vol. 4 no. 3, (2004), pp. 221-239.

[2] J. Yuan and J. Yu, "Tourism demand for electronic commerce and its development pattern," technology \& Economy in Areas of Communications, vol. 6, (2006), pp. 108-113.

[3] Y. Li, "A Study on the Problems and Counter-measures in the Development of China's Tourism Electronic Business," Tourism Tribune, (2001), pp. 56-68.

[4] D. G. Pearce, "Tourism Today: A Geographical Analysis," Longman Scientific \& WE hnical, (1987), pp.45-68.

[5] H. Werthner and F. Ricci, "E-commerce and tourism," Communications of the ACM, (2004).

[6] P. Constanta, M. Marazakis, D. Papadakis, "Efforts towards an open electronic commerce infrastructure for the tourism industry", Database and Expert Systems Applications, (1998), pp.633-637

[7] J. Murphy and A. Scharl, "An investigation of global versus local online branding," International Marketing Review, vol. 24 no. 3, (2007), pp.297-312. 
[8] A. P. Williams and A. J. Palmer, "Tourism destination brands and electronic commerce: Towards synergy?" Journal of Vacation Marketing, vol. 3, (1999), pp.263-275.

[9] D. Buhalis, "Strategic use of information technologies in the tourism industry," Tourism management, vol. 19 no. 5, (1998), pp.409-421.

[10] D. Buhalis and R. Law, "Progress in information technology and tourism management: 20 years on and 10 years after the Internet-The state of e-Tourism research," Tourism management, vol. 29 no. 4, (2008), pp.609-623.

[11] J. Xiong; C. Liu and Y. Jun, "Rural tourism electronic commerce development and network system," Economic Geography, vol. 2, (2006), pp. 67-74.

[12] D. Lin and X. Guo, "Tourism electronic commerce research review," Tourism Tribune, vol. 5, (2008), pp. 34-54.

[13] C. Zhou, J. Yang and Z. Yu, "Tourism e-commerce sites content delivery measurement and evaluation research," Tourism Tribune, vol. 12, (2010), pp. 102-106.

[14] L. Zheng, "China's tourism electronic commerce development and key factors analysis," Reformation \& Strategy, vol. 7, (2009), pp. 14-17.

[15] J. Qin, "Tourism electronic commerce research progress and foresight," Sichuan ltd. College Journal, vol. 1, (2004), pp. 98-101. 